University of Nebraska - Lincoln

DigitalCommons@University of Nebraska - Lincoln

Agronomy \& Horticulture -- Faculty Publications

Agronomy and Horticulture Department

$1-1986$

Registration of NP23 and NP24 Sudangrass Germplasms

Herman J. Gorz

United States Department of Agriculture

Francis A. Haskins

University of Nebraska-Lincoln, fhaskins@neb.rr.com

K. P. Vogel

United States Department of Agriculture, kvogel1@unl.edu

Follow this and additional works at: https://digitalcommons.unl.edu/agronomyfacpub

Part of the Plant Sciences Commons

Gorz, Herman J.; Haskins, Francis A.; and Vogel, K. P., "Registration of NP23 and NP24 Sudangrass Germplasms" (1986). Agronomy \& Horticulture -- Faculty Publications. 253.

https://digitalcommons.unl.edu/agronomyfacpub/253

This Article is brought to you for free and open access by the Agronomy and Horticulture Department at DigitalCommons@University of Nebraska - Lincoln. It has been accepted for inclusion in Agronomy \& Horticulture -Faculty Publications by an authorized administrator of DigitalCommons@University of Nebraska - Lincoln. 


\section{REGISTRATION OF NP23 AND NP24 SUDANGRASS GERMPLASMS}

NP23 and NP24 sudangrass [Sorghum bicolor (L.) Moench] (Reg. no. GP-178 and GP-179) populations, developed cooperatively by USDA-ARS and the Nebraska Agricultural Research Division, were released in April 1984. NP23 and NP24 were derived from 'Greenleaf' by selection for lower and higher dhurrin content, respectively. Both populations resemble Greenleaf in general appearance with sweet, juicy culms (dull or green midribs), dark green color, late maturity, excellent leafiness and disease resistance, and both tan and purple plant color. Glume colors include black, mahogany, and sienna; pericarp color is brown. Glumes become detached from some of the seeds during threshing. In A1 cytoplasm, NP23 and NP24 are restorers. NP23 and NP24 should be of value in studies comparing strains of sudangrass derived from the same germplasm source but differing primarily in dhurrin content. NP23 also has potential value for use in breeding sudangrasses with lower dhurrin content and in the production of low-dhurrin sorghum-sudangrass hybrids.

NP23 and NP24 were developed by selecting for lower and higher dhurrin content, respectively, in each of six cycles of recurrent phenotypic selection. Details of the first two cycles of selection were reported previously (2). After the second cycle of random mating in separate low-and high-dhurrin isolation plots, seed was harvested from individual plants. Seedlings grown from these plants were assayed for dhurrin content (1). Seed was bulked from the 
15 lowest plants from the low-dhurrin population, and another bulk was formed from the 15 highest plants from the high-dhurrin population. These bulks were random-mated in separate isolations to provide source material for three additional cycles of selection in each of the two populations. Each of these three cycles consisted of approximately 100 plants per population selected from 265 to 300 individually assayed seedlings, except that 229 seedlings were assayed in the sixth cycle of the high-dhurrin population. Selected plants in each cycle were transplanted to separate low- and high-dhurrin isolated field plots for random mating. Equal numbers of seeds harvested from individual plants were bulked at the end of each cycle to provide source material for the next cycle of selection. Equal volumes of seeds from all sixth cycle plants within the low-dhurrin population were bulked to form NP23, and similar bulking within the highdhurrin population formed NP24.

The spectrophotometric assay (1) for hydrocyanic acid potential of first leaves from 1-week-old seedlings grown in the same test resulted in the following values for means and standard errors $\left(\mathrm{mg} \mathrm{kg}^{-1}\right.$ fresh weight, bulk of 10 seedlings per replication, five replications): NP23 - 399 \pm 21 ; NP24 - $744 \pm 19$; Greenleaf $-532 \pm 40$; 'Piper' -381 \pm 36 ; and NP 22-308 \pm 17 .

Seed can be obtained in germplasm lots from the Department of Agronomy, University of Nebraska, Lincoln, NE 68583 .

\section{H. J. Gorz, F. A. Haskins, and K. P. Vogel (3)}

\section{References and Notes}

1. Gorz, H.J., W.L. Haag, J.E. Specht, and F.A. Haskins. 1977. Assay of $p$-hydroxybenzaldehyde as a measure of hydrocyanic acid potential in sorghums. Crop Sci. 17:578-582.

2. ---, F.A. Haskins, and K.P. Vogel. 1982. Divergent selection for hydrocyanic acid potential in sudangrass. Crop Sci. 22:322-325.

3. Supervisory research geneticist, USDA-ARS; George Holmes professor of agronomy; and supervisory research geneticist, USDA-ARS, Dep. of Agronomy, Univ. of Nebraska, Lincoln, NE 68583. Cooperative investigations of USDA-ARS and the Nebraska Agric. Res. Div. Published as Paper no. 7725, Journal Series, Nebraska Agric. Res. Div. Registration by Crop Sci. Soc. of Am. Accepted 19 July 1985. 